\title{
Formål og mål i New Public Management - ressource, begrænsning, trivialitet eller byrde?
}

\author{
Af Jan Mouritsen *)
}

Ét vigtigt princip for New Public Management (NPM) er, at mål er en god måde at konkretisere udviklingsønsker på. Udgangspunktet er, at formål skal oversættes til et nuanceret målhierarki. Dette målhierarki antages at fylde formålet ud med mål. Dilemmaet er her, at mål sjældent er det samme som de formål, man ønsker at fremme, men er kvantificeringer defineret i forlangelse heraf. Det er en styringsform, som driver forandring ved at insistere på, at det er muligt, om end på det givne tidspunkt uklart, hvordan at skabe ikke blot forandring, men forbedring. Da forandring ikke er det samme som forbedring, er der et muligt gap mellem formål og mål. Men hvordan ser et sådant gap ud? $\mathrm{Og}$ hvordan ville en ledelsesmæssig indsats kunne hjælpe med at håndtere det? Dette todelte spørgsmål organiserer denne artikel.

\section{A. Relationen mellem formål og mål}

Analytisk drejer formål sig typisk om kvalitative aspirationer, mens mål er kvantificeringer.

Formålet med uddannelse er at skabe en vidende og kunnende befolkning; målet er, at alle skal have et eksamensbevis. Formålet med sundhedsvæsenet er at helbrede og forebygge sygdom; målet er at reducere ventelister til hospitalsbehandling, og at KRAM indikationer er gode for en vis \%-del af befolkningen. Formål og mål er forskellige, og den forskel kan være et problem, hvis mål gøres til formål. Dette er en af NPM's risici, som er en effekt ikke af, at NPM ikke fungerer, men af at den fungerer. NPM er særligt innovativ, når denne forskydning realiseres. Det hænger sammen med, at NPM har en frihedsambition. Med NPM skabtes et organisationsdesign, hvorefter institutionen gives mange flere beslutningsrettigheder end førhen.

*) Jan Mouritsen er professor på Institut for Produktion og Erhvervsøkonomi på CBS. 
I stedet for at styre på input insisterer NPM på den frihed, at institutioner kan sammensætte inputs, som de ønsker, og dette er med til at udvikle innovation. Den frihed kan gøre institutioner til 'firmaer', der kan skabe deres egne strategier, deres egne kompetencer og deres egne profiler. De er 'firmaer,' fordi de kan tillades at udvikle særlige tilbud til særlige grupper af brugere med penge i ryggen via f.eks. taxametertilskud eller anden aktivitetsrelateret finansiering (Mouritsen, 1997).

Denne historie om frihed, delegering og innovation forudsætter, at den enkelte institution har et mål at allokere ressourcer efter. Institutioner har givetvis artikulerede formål, men målet bliver let et omdrejningspunkt, fordi det via dets kvantificering kan indgå i kalkulationer af konsekvenser af forskellige beslutninger om ressourcer og blive en del af allokeringsprocesser. Budgettet handler om målet, og her kan formålet let være vanskeligt, fordi det kun kan tilgodeses i de allokeringer til særlige formål, der kan ske i et budget. Formål er her undtagelser eller specielle projekter. Hovedgrebet i budgettet er målet, fordi det autoriserer, at man kan bruge penge. De fleste institutioner har kun penge pga. målet; ikke pga. formålet. Hermed forskyder NPM formål til mål.

Denne forskydning betyder, at man kan blive forundret over, hvad der sker i offentlige institutioner. Pga. frihed viser det sig efter sigende, at nogle universiteter udvikler studier, som der ikke er behov for, men som tilgodeses af et taxameterprincip. Efter sigende kan man i sundhedssektoren finde eksempler på overbehandling, fordi afregning sker efter et aktivitetsprincip. Sådanne effekter kommer af frihed. Det er ikke primært frihed til at tænke frit, men frihed til at benytte administrative teknikker til at nå sine mål. Mål leder til målstyring, der leder til (grader af) målopfyldelse. Det er et kybernetisk system. Derfor er der brug for mål, som ikke er for tvetydige, og for at insistere på klarhed fokuseres der ofte på generelle, men alment kvantificerbare mål: budgetoverholdelse, produktivitet og brugertilfredshed. Sådanne mål kan være en del af en allokeringsproces; ikke mindst kan de delegeres, så andre, der er placeret rigtigt mange forskellige steder i institutionen, kan benytte samme beslutningsprincip. Så kan 'alle' lige pludselig blive del af en større mekanisme, som tilsammen gør målstyring til en praksis. Et princip om målstyring distribueres gennem regler. Det er langt vanskeligere at distribuere noget via formål, der ofte er formuleret med brede begreber, der næppe lader sig binde inde i beslutningsregler. Man kan sige, at mål og målstyring skaber aktørers rationalitet ved, at de med 
teknologisk støtte i informationssystemer og allokeringsprincipper udpeger indholdet i og overvejelser bag beslutninger (Mouritsen, 2016; Mouritsen \& Kreiner, 2016).

Et interessant eksempel på forskydningen fra formål til mål er beskrevet af de to amerikanske sociologer Wendy Espeland og Michael Sauder (2007, 2016; 2009), som stillede spørgsmålet, hvordan offentlige rangordninger af juridiske institutter fungerer. Et juridisk magasin ønskede at hjælpe studenter med at vælge universitet. Derfor lavede de et system, hvorefter juridiske institutter blev rangordet efter en lang række kriterier i forhold til akademisk miljø, studentermiljø, beskæftigelsesmuligheder, undervisningskvalitet mv. Det lyder som en god ide at studenter skal have et oplyst grundlag til at vælge uddannelsessted, måske særligt i USA, hvor uddannelse er dyr. Espeland og Sauder fandt ud af, at sådanne rangordninger ikke forblev beskrivelser af kvaliteter ved disse universiteter. I stedet begyndte universiteter at indrette sig efter de mål, som rangordningen ledte frem til. Universiteter begyndte at ændre curriculum. De begyndte at investere i ting, som har med faciliteter mere end med forskning og undervisning at gøre. De begyndte at investere i marketing for at gøre mulige arbejdsgivere interesserede i universitetet, og de begyndte at selektere studenter, så den del, der ville reducere eksamensgennemsnittet, ville få det vanskeligt at komme ind. Desuden øgede det også både studenters og deres forældres bekymringer, fordi nu blev det tilsyneladende klart, at det ville kunne få fatale konsekvenser ikke at komme ind det rette sted. Det, som skulle skabe overblik for at gøre beslutninger mulige i et heterogent marked, skabte bekymringer for beslutningstagere (studenter og forældre) og uniformitet i markedet, da universiteterne søgte at tilnærme sig det samme ideal. Dette ideal var et mål, som rangordningen fastsatte. Dette mål var stærkt nok til at ændre universiteternes formål, fordi dette skete, selv om alle ledere og ansatte (i begyndelsen) bestred, at målet var en god substitut for formålet.

Wendy Espeland og Michal Sauders analyse er et interessant bidrag til at forstå relationen mellem formål og mål. Formålet er det kvalitative og altomfattende rammeværk, som imidlertid er vanskelige at benytte til ressourceallokering. Formålet er ubegrænset, og dermed har det heller ikke megen autoritet i et organisatorisk system, hvor der skal tages beslutninger på mange niveauer og i mange sammenhænge på én gang. Når beslutningstagning er så distribueret, har formål ikke så meget at sige. Det er målet, som kan holde beslutningstagning i gang. Det er sjældent, at en sådan forskydning kommer uden sværdslag. Formål er nemlig identitet i mange institutioner. 
En mulig reaktion herpå er, at denne målforskydning leder til dekobling. Det er en velbeskrevet praksis, at institutioner forsøger at vride sig uden om mål og holde fast i formål. I den forstand søger institutioner at gøre mål til trivialiteter. Her skabes der skuespil og måske mistillid. Man tolererer mål, når man kan få dem til ikke at gøre videre væsen af sig. Her udvikles den type hykleri, som Niels Brunsson (1993, 2006) taler om. Institutioner har ikke blot en handlingsorganisation, de har også en taleorganisation, som bruger kræfter på at lade, som om man følger mål, men måske mere er optagne af at skabe luft og slack. Det er naturligvis en sådan observation, som kan irritere politikere og kan få dem til at vurdere, at det altid er muligt at øge produktivitet. Modsvaret til dekobling er grønthøstermetoden. Man kan forvente, at svaret (dekobling) og modsvaret (generelle indskrænkninger) skaber mere af det oprindelige svar og etablerer generel mistillid. Denne mistillid er ikke forankret i formålet. Den er forankret i målet.

En anden reaktion er, at hensynet til mål skaber en ny byrde. Nogle gange er målet, som Espeland og Sauder siger, ikke blot et hensyn til et outcome; det kan også være et hensyn til en særligt accepteret produktionsfunktion, som i tilfældet af universiteter er, at der findes et bestemt og invariant ideal. Dette ideal kan blive nok så meget af en byrde, at ikke blot formålet men også målet mister fart. Et dansk eksempel er måske den sundhedsplatform, som efter sigende skaber nok så mange problemer på sygehuse på Sjælland. Disse problemer er med til at reducere målopfyldelse, da færre patienter kommer under behandling. De er også med til at reducere formålet, fordi sundhedsplatformen efter sigende kraftigt øger risikoen for fejlmedicinering og fejlbehandling. Den står tilsyneladende også i vejen for kræftpakkens mål. Her er den teknologi, som skulle hjælpe målet i gang, med til at umuliggøre dets realisering. Den er en byrde, som får målet til at falde sammen under vægten af målinger, som sundhedsplatformen pålægger personalet at udføre. Det betyder, at institutioner kan komme til at handle og gøre ting, som de ved er kontraproduktive. Som teknologisociologen Claudio Ciborra (2000, 2002) påpegede allerede for mange år siden, er det ret sandsynligt, at moderniseringen bringer risici med sig, som især viser sig i design af store IT systemer, bl.a. fordi det ikke rigtigt er gjort klart, om, eller i hvilken forstand, de skal strukturere menneskers arbejde, eller de skal hjælpe mennesker med at udføre et bedre arbejde (Adler \& Borys, 1996). Når de gør menneskers arbejde vanskeligere, er de en byrde; men de behøver naturligvis ikke at være en byrde for alle. De kan være en byrde for nogle og på grund heraf være en lettelse for andre. Det er noget af det, der opleves, når mange sættes til at registrere, for at andre kan få en opgave med at sortere og håndtere sådanne registreringer. 
IT systemer er ikke de eneste eksempler på, at mål kan virke som en byrde. Problemet er mere generelt og hænger sammen med det helt paradoksale, at NPM på den ene side forudsætter individualitet for institutioners strategi, og på den anden side udvikler en hoben mekanismer via standarder, der skal være fælles, og som derfor virker imod denne ambition. Det er en byrde, at institutioner på den ene side har ansvar for sig selv, og alligevel på den anden side struktureres af best practices og andre designtiltag, som er institutionelle svar, som gør institutioner ens, og alligevel insisterer på, at institutioner gennem strategi skal være forskellige. Det skaber ret sikkert både byrder og trivialitet, fordi forpligtelse om ensartethed er vanskelig at forene med den individualiserende strategi, som NPM postulerer (Kurunmäki \& Miller, 2011).

Man kan overraskes over, hvorfor mål(styring) sjældent præsenteres som en ressource. Man hører naturligvis om, at det er vanskeligt at koordinere og kontrollere uden mål(styring). Det er sikkert rimeligt, at politikere ved, hvad der sker i institutioner og samfundet generelt, fordi de ellers ville være blinde i deres problemformuleringer og indsatser. Transparens er nok en god ide for et demokratisk samfund. Men det er ikke det rationale, man knytter til mål(styring).

Det er interessant, at det er vanskeligt at se mål(styring) som en ressource. Det hænger paradoksalt nok sammen med friheden! Det er netop pga. NPM's frihedsideal, at institutioner ser mål som begrænsninger snarere end som ressourcer. Det hænger sammen med, at frihed er en forpligtelse til at tænke nyt; forpligtelsen til at institutioner skal 'tænke med' om håndteringen af samfundets problemer. De skal gennem innovation hjælpe samfundet med at opfinde nye problemstillinger og nye løsninger på de generelle og permanente hensyn til budgetoverholdelse, produktivitet og brugertilfredshed. Dette betyder, at institutioner snarere end at få at vide, hvad de skal lave, og hvordan de skal gøre det, er forpligtede på at innovere. Innovation er med den berømte økonom Joseph Schumpeter’s (1943) formulering 'kreativ destruktion.' Iflg. Schumpeter skabes innovation ved, at entreprenører ændrer industriers struktur. Der er tale om kreativitet, fordi der skal stor forestillingsevne til at tænke sig nye industrielle strukturer, men der er også tale om destruktion, fordi manges livsbetingelser ændres bl.a. ved, at deres jobs forsvinder i kreativitetens navn. Kreativitet følges derfor af kaos. Det er relevant for mål(styring), som med henvisning til innovation skaber forandringer, der (også) er destruktive på en eller flere måder. Det betyder, at mål(styring), når den fungerer 'rigtigt,' vil skabe problemer om end ikke direkte kaos. Det paradoksale er, at den som ressource let kan komme til at skabe fortvivlelse og en fornemmelse af, at verden er af lave. Alt er flydende, at alle værdier skal gentænkes, og at alle 
institutioner er labile. Det kan være, at dette skaber budgetoverholdelse, produktivitet og kundetilfredshed, men det skaber næppe glæde over innovation i institutionen for de mange, hvis situation skal 'destrueres.' Derfor anerkendes mål(styring) sjældent som en ressource, men som en begrænsning.

\section{B. Ledelse af og igennem mål}

Et mål(styringssystem) er et design. Det er et stykke skrivebordsarbejde, som primært eksisterer som papir, i PowerPoint præsentationer, i kalkulationer eller via debatter. Det tager form gradvist samtidig med, at mål udpeges. Der er naturligvis mange typer af mulige mål, men de, som holder i lang tid, bygges op omkring infrastrukturer af information, der kan stabilisere målenes (matematiske) definitioner samtidig med, at de gøres reviderbare. Det er denne infrastruktur, som gør institutionalisering af mål mulig.

Institutionalisering af målenes infrastruktur er, hvad der gør centralisering mulig. Det er en paradoksal effekt af NPM, hvis ambition om frihed ville insistere på at lave infrastruktur for at sprede magt. Imidlertid er centralisering en mere sandsynlig effekt, fordi mål bliver ved med at findes for alle institutioner. De er umulige at undgå. Det betyder, at rangordning er mulig. Men det betyder ikke, at rangordning er effektiv altid og alle steder. Det betyder ikke, at magt og kontrol (at være i kontrol) hænger sammen. Det er muligt, at magt definerer mål, men som vist ovenfor, betyder dette ikke nødvendigvis, at man kan kontrollere konsekvenserne af mål. Derfor er designstrategi næsten altid tvetydig. Der skal mere til i form af handlingsstrategier. Sådanne handlingsstrategier er de indgreb, der hele tiden skal til for at designstrategien ikke udarter alt for meget. Handlingsstrategier udsætter konsekvenserne af de spændinger, som der næsten altid er i en designstrategi. Eller med andre ord, det kan være, at handlingsstrategier gør formål noget vigtigere, end de er i en designstrategi, der fokuserer på mål.

Problemet med designstrategier er, at de gør virkeligheden (for) klar. Det er et problem, fordi klarhed sjældent er en konsekvens af, at alle situationens problemstillinger er afvejet og organiseret i forhold til hinanden. Klarhed kommer af at bortse fra det, der skaber forvirring (Mouritsen, 2016). Mål er klare, fordi uklare forhold er udeladt. Man hører f.eks., at klare mål for studenters studiefremdrift fremmer studenters overgang til erhvervslivet. Et problem ved denne pointe er imidlertid, at det så betyder, at de fleste studenter bliver færdige lige før sommer, og da 
virksomheder ikke ansætter personale i sommerperioden, er der lige pludseligl flere arbejdsløse i statistikken, end der plejede at være. Det klare mål at støtte studenter i at færdiggøre uddannelse inden for normeret tid er konsistent med universitetets mål om at sikre sig bonus for hurtig gennemførelse, men om det er konsistent med formålet med at sikre overgangen til erhvervslivet, er ikke klart. Ved at gøre målet klart for universitets beslutningsprocesser afskærer man den forvirring, der kunne opstå, hvis man fokuserer på formålet at lette overgangen til erhvervslivet. Sådan fungerer mål. De er klare, fordi de undlader at tage visse ting i betragtning og ikke, fordi de har resolveret alle de konflikter, der kunne ligge i et formål. Derfor forudsætter klarhed, at man bortser fra det vanskelige.

Hvordan ville handlingsstrategier kunne reagere på en sådan konsekvens af designstartegier? Lad os sige, at handlingsstrategier er ledelse, dvs. en forpligtelse til at sætte sig mellem en situation og aktuelle eller potentielle effekter. Lidt romantisk kunne det udtrykkes som en forpligtelse til at sætte sig tættere på formål. Der kunne her komme en konflikt, fordi ledelse så ville dreje sig om at oversætte - i betydningen ændre på eller føje til (snarere end at nedbryde, som er logikken i målhierarkiet) - nogle aspekter, der kunne komme på kant med mål(styringen).

\section{Regne/regne den ud}

Det første princip for handlingsstrategi kunne være, at der er forskel på at regne og at regne den ud. Det kunne f.eks. betyde, at universiteter nok har målet om, at studenter skal færdiggøres inden for normeret studietid, men samtid ved universitetet godt, at der er slack i proceduren for tildeling af bonus, så et vist overløb på tidsforbrug er acceptabelt i forhold til bonusbetaling. Derfor er den lokale tilretning af målet ikke nødvendigvis normeret tid, men normeret tid plus den sikkerhedsmargin, der ligger i bonussystemet. En sådan tilføjelse vil give den studerende lidt mere slack, og det vil gøre, at den periode, hvor akademisk personale er optaget af at være eksaminatorer og censorer for andre studerende, ikke overlapper med den periode, hvor studenten skal have maximal vejledning for at færdiggøre sine studier. Teknisk set betyder dette, at universitets bonusbetaling bliver mere risikobetonet, men hvis den lokale tilføjelse er, at studenten får særlig opmærksomhed senere, så nås målet om normeret tid + tre måneder måske mere sandsynligt. Pointen er, at ledelse her drejer sig om at tilføje noget, som muligvis relativerer målet, men ikke gør det absurd og måske endda mere opnåeligt. Det betyder, at man måske godt kan udregne en tidsplan for færdiggørelse af studietiden, men den er forskellig fra at regne ud dvs. gennemskue - hvordan tidsplanlægning og koncentreret vejledning hænger sammen. 


\section{Se/ indse}

Det leder til det andet princip, som kunne være, at der er forskel på at se og at indse. Mål gør ting transparente og gør det muligt at se et sagsforhold. For eksempel er det muligt gennem undersøgelser af medarbejdertilfredshed at konkludere, at der ofte er en positiv sammenhæng mellem tilfredshed og produktivitet eller kvalitet. Derfor kan man se, at investering i aktiviteter, der øger tilfredshed, sikkert vil forbedre produktivitet eller kvalitet. Men hvad ville der ske, hvis kvalitet eller produktivitet faldt? Det, man kan se, er, at skal der investeres mere i medarbejdernes tilfredshed, men er det, hvad der sker? Der sker ofte det modsatte. Der kommer fyringer, der kommer omplaceringer, og der reorganiseres (Murthy \& Mouritsen, 2011). Det er lige pludseligt en helt anden teori om tilfredshed, som ikke fremgår af det, der kan ses. Men den anden teori er muligvis enkel at indse, hvis man gjorde forsøget og byggede på sin erfaring. Det, som skal indses, drejer sig om randbetingelsen for, at målets rationale er realistisk. Det, man hermed kan indse, er, at den empiriske klarhed er et lille udsnit af den verden, lederen er optaget af. Der er flere ting på og i spil end det, der kan ses. Derfor er handlingsstrategien nok ikke rettet mod alene at skabe sammenhæng mellem tilfredshed og produktivitet/kvalitet. Mange andre ting bidrager også til produktivitet og kvalitet, hvilket betyder, at tilfredshed måske er en effekt af noget helt andet, for eksempel at der er tværorganisatorisk kommunikation og vidensdeling, fokus på udvikling af aktiviteter, interesse i brugerens, klientens elle kundens situation og anerkendelse af fleksibilitet. Alle sådanne forhold findes på samme tid, som der findes tilfredshed, og alle disse ting er også med til at definere betingelserne for produktivitet og kvalitet (Boedker, Meagher, Vidgen, Cogin, \& Mouritsen, 2017). Dette skal indses, og måske skal handlingsstrategien slet ikke handle om tilfredshed, som målet insisterer på, men mere om organisation samarbejde, innovation, kommunikation og udvikling. Måske er det, man kan se, et fatamorgana; det betydningsfulde skal måske indses.

\section{Høre/lytte}

Endelig kan en tredje handlingsstrategi handle om at lytte $i$ stedet for at høre. Efter sigende er det (mere og mere) normalt, at kommunikation mellem medarbejdere og ledelse sker via sætningen: ”Jeg hører, hvad du siger", og så ved alle, at der ikke kommer til at ske ret meget. Det skyldes måske ikke, at ledere ikke vil lytte efter, men at de ikke kan, fordi andre forhold i institutionen gør forandring umulig. Når man hører, er man optaget af lyde; når man lytter, leder man efter lukkede argumenter eller rum, hvorfra man kunne gentolke eller tilføje viden, så det, der siges, udvikles. 
Det er ofte tilfældet, at det er vanskeligt for personer at lytte, fordi de allerede er viklet ind i visse institutionelle spil. Det kan f.eks. godt være, at det ville være en god ide at se fleksibelt på færdiggørelsesterminen på universiteterne, men det kan også være skræmmende, fordi målet ikke giver lov til det. Og når målet ikke giver lov til det, så kan man kun høre kritikken og ikke lytte efter, om der i kritikken også er kimen til en løsning. Handlingsstrategien med at lytte med - og ikke alene høre lyden - drejer sig om at indse, om et indspil kunne bære kimen til nye løsninger.

Alle tre typer af handlingsstrategier forudsætter ledere; de forudsætter ikke blot designs. Ledelse indebærer, at man ikke er helt så fokuseret på mål, men på alt det andet, som kunne lede til mål. Studenten skal nok ikke primært være optaget af færdiggørelsestermin, men på møder med sin vejleder. Sygeplejersken skal nok ikke primært være optaget af kvalitetsindikatorer, men af at observere patienten, og lederen skal ikke lade sig forlede af mål. Det skyldes ikke mindst, at det er tvivlsomt, om fokus på mål er effektivt. Det er i det mindste den berømte økonom John Kay’s (Kay, 2010) pointe:

"Complex goals are often best pursued indirectly. The happiest people are not the ones who aggressively pursue happiness. The most profitable companies are not the most profit-oriented. The most wealthy people are not the most materialistic ones."

Derfor er handlingsstrategier interessante. De er de indirekte veje til resultater.

\section{Målstyring og udviklingen af NPM}

Ovenstående diskussion handler om kun ét aspekt af NPM, men det er et aspekt med så stor generalitet, at det ikke berøres af de mange mulige definitioner og aspirationer, der eksisterer for den offentlige sektors indretning. Den flerhed af styringsparadigmer, som Bøgh Andersen m.fl. (2017) formulerer, laver interessante distinktioner mellem strategier for styring af den offentlige sektor. Imidlertid er de alle designstrategier, der indeholder ambitionen om formål, der skal nedbrydes til et målhierarki. Disse styringsparadigmer antages på forhånd af handle om styring på distancen, altså langt fra de steder, hvor produktion foregår. Men denne ambition bortser fra problemet med oversætte fra formål til mål. Den bærende ide er stadig, at formål fyldes ud af mål og delmål. 
Imidlertid er det, som argumenteret ovenfor, måske endda mere sandsynligt, at problemet drejer sig om, at mål allerede trivialiserer formål, eller at de får mennesker til at gøre noget kontraproduktivt. Mål er derfor ikke en udfyldning af formålet; de er en forskydning af formålet. Denne forskydning har muligvis gode effekter, fordi den gør det muligt at delegere beslutningskompetence og dermed gør handling mulig. Imidlertid skaber de også spændinger, fordi formål formuleres etisk og narrativt, mens mål formuleres teknologisk og strategisk. De skaber derfor spændinger og dilemmaer, som ikke kan løses, men som hele tiden skal medieres gennem handlingsstrategier.

Derfor er den diskussion, som handler om styringsparadigmer, måske ikke helt så relevant. Over tid udvikles sikkert en buket af elementer, som tager lidt herfra og noget andet derfra. Denne hybridisering er måske en interessant paradigmediskussion, men den er knappest en interessant ledelsesdiskussion. Der vil under alle omstændigheder være en opgave og et dilemma i at få designstrategier til 'at virke,' og det sker næppe gennem paradigmer, som, når det kommer til stykket, alle forudsætter et samlende perspektiv fra en stat, som derfor skal formulere formål. Problemet med NPM er så, at den forudsætter en ansats, hvor institutioner er frie, hvilket vil ske under alle styringsparadigmerne, og det indebærer stadig, at de skal skabe innovation, herunder ikke blot kreativitet men som følgevirkning også destruktion. Det er i følgevirkningen, at ledelsesopgaven, handlingsstrategierne, kommer til at optræde. De store paradigmer kan ikke løse følgevirkninger; det kan handlingsstrategier muligvis.

Når handlingsstartegier kun muligvis kan løse problemer, hænger det sammen med, at handlingsstrategiers mulighedsrum er alt det, der i tillæg til det, der kan ses, også handler om det, der skal indses, alt det, der skal regnes ud (i tillæg til udregnes), og alt det, der skal lyttes til (i tillæg til høres). Det er et stort rum. Man kan navigere forkert, der kan komme fejlslutninger, man kan lære det forkerte af sine erfaringer. Derfor er handlingsstrategier på vej ind i det dilemma, at de på den ene side forudsætter forglemmelse af de mål og tiltag, man lærer, er uhensigtsmæssige; på den anden side forudsætter de tilgivelse, fordi de gennem destruktion går ud over (ret mange andre) mennesker (Mouritsen \& Kreiner, 2016). Det er tvivlsomt, om forglemmelse og tilgivelse bliver ledelsesidealer i NPM, men det er måske relevant at spørge, om udviklingen af det ledelsesmæssige rum betyder, at mål skal hjælpe med at få samtale til at fungere (Busco \& Quattrone, 2017), eller om de er til hjælp for dem, der vil undgå at lytte (Strathern, 2000). 


\section{Konklusion og implikationer}

Sammenhængen mellem formål og mål er ukomplet. Det kan man ikke gøre meget ved. Denne ukomplethed skaber dilemmaer, der næppe kan løses, men som fordrer at blive håndteret. Det nytter sikkert ikke meget at insistere på, at institutioner skal frasige sig mål, fordi så er der ikke nogen mekanisme, der kan autorisere til at bruge penge. Det er nok heller ikke fremkommeligt at insistere på, at professionalisme skal have en større vægt, fordi også professionalisme betyder i mange sammenhænge, at der skal flere mål(inger) til. F.eks. forudsætter store dele af den offentlige drift, at der er viden til rådighed, som kun kan findes gennem mål(inger), herunder hospitalsdrift, som bygger på blodprøver. Hospitaler er informationsintensive. Når denne information fejler, skaber man problemer, hvilket Sundshedsplatformen illustrerer.

Den pågående diskussion af, om man kan gøre NPM mere menneskelig ved at insistere mindre på mål(inger), er umiddelbart populær, fordi målingsregimet synes at blive relativeret. Det er dog ikke så klart, om dette er rigtigt. Det kan være, at der bruges (relativt) færre ressourcer på at måle, men det vil ikke reducere forskellen mellem formål og mål. Det kan også være, at reduktion af mål(ingsarbejdet) vil reducere fornemmelse af overvågning. På den anden side vil dette i sig selv ikke øge kapaciteten til at lytte. Det er også muligt, at reduktion af mål(ingsarbejdet) kan skabe større medarbejdertilfredshed, men det stopper ikke hensynet til produktivitet og dermed kontinuerte reduktioner i ressourcer per aktivitet. Derfor er forestillingen om at menneskeliggøre mål(ingsarbejdet) ikke en universalløsning. Det kan endda være, at reduktion af mål leder til mere komplicerede og sammensatte mål, fordi hvert enkelt mål skal sammenfatte flere andre, og det vil øge kompleksitet og dermed uklarhed.

NPM kommer derfor næppe til at virke anderledes, hvis den blot'slankes' eller gøres mere 'menneskelig.' Hvis der er et alternativ, skal det nok findes i, hvordan man gør mål(inger) relevante ved at gøre de, der kan bestemme målenes randbetingelser, mere ansvarlige. Det er velkendt fra visse dele af Human Resources Management litteraturen, at personers indsats dels skyldes deres kompetencer og motivation, som er individuelle, og dels de muligheder, som institutionen stiller til rådighed for deres indsats (Boselie, Dietz, \& Boon, 2005). Mål(inger) anvendes til at håndtere incitamenter, som drejer sig om motivation, men de benyttes ikke rigtigt til at vurdere, om personen eller institutioner har muligheder for at fremme deres formål. Det hænger sammen med, at et øvre niveau skal kontrollere et underliggende niveau. Hvis der skulle 
noget andet til, ville det være at sætte mere fokus på mulighedsrummet. Det ville indebære, at det overliggende niveau ville skulle blive ansvarlige for den underliggende niveaus resultater.

Det lyder fjollet, men er det ikke helt. Hvis institutioner, som pt. har rigtigt mange rutiner til at ansætte folk og dermed er professionelle i deres HR aktiviteter, kunne antages at have ansat personer, som kan noget om det sagsforhold, de sættes til at forvalte (kompetence), og også kan antage, at de kun vælges, hvis de er fornuftige (motivation), så er den eneste grund til manglende mål(opfyldelse), at randbetingelserne er problematiske. Det ville være en styringsform, der gjorde ansvaret for at stille rammer op helt eksplicit. Den ville lægge et ansvar for rammer der, hvor de fastlægges. Denne styringsform ville lægge vægt på, at de, der har viden om mål gennem mål(inger), også kommer til at skulle svare på, hvordan den viden er administreret. Det ville være en styringsform, som kobler viden og ansvar sammen. Dette er vigtigt i forbindelse med mål(styring), fordi den sammenhængende viden om samfundet og dets institutioner findes i de infrastrukturer af information, som skabes og centraliseres igennem mål(inger). Paradokset er, at de, der foretager målinger, ved mindre om mål(opfyldelse), end de institutioner, der gør komparativ viden om institutioner klar gennem den infrastruktur af viden. Det store spørgsmål er her, om de, der administrerer mål(inger), kan gøres ansvarlige for deres analyser og forslag. Kan de gøres så ansvarlige, at et eventuelt bud på, hvor meget der kan spares i den offentlige sektor, hvis alle var ligeså produktive som den mest produktive institution, ville skulle falde tilbage på dem snarere end på institutionerne? 


\section{Referencer}

Adler, P. S., \& Borys, B. (1996). Two Types of Bureaucracy: Enabling and Coercive. Administrative Science Quarterly, 41(1), 61. https://doi.org/10.2307/2393986

Boedker, C., Meagher, K., Vidgen, R., Cogin, J., \& Mouritsen, J. (2017). Doing more with less: productivity or starvation? The Intellectual Asset Health Check. Public Money and Management, 37(1). https://doi.org/10.1080/09540962.2016.1249229

Bøgh Andersen, L., Greve, C., Klaudi Klausen, K., \& Torfing, J. (2017). Offentlige styringsparadigmer: Konkurrence og sameksistens. København .

Boselie, P., Dietz, G., \& Boon, C. (2005). Commonalities and contradictions in HRM and performance research. Human Resource Management Journal, 15(3), 67-94. https://doi.org/10.1111/j.1748-8583.2005.tb00154.x

Brunsson, N. (1993). Ideas and actions: Justification and hypocrisy as alternatives to control. Accounting, Organizations and Society, 18(6), 489-506. https://doi.org/10.1016/03613682(93)90001-M

Brunsson, N. (2006). Mechanisms of hope: Maintaining the dream of the rational organization. Copenhagen: Copenhagen Business School Press.

Busco, C., \& Quattrone, P. (2017). In Search of the "Perfect One": How accounting as a maieutic machine sustains inventions through generative 'in-tensions.' Management Accounting Research. https://doi.org/10.1016/j.mar.2017.02.002

Ciborra, C. U. (2000). From control to drift, The dynamics of corporate information infrastructures. Oxford.

Ciborra, C. U. (2002). The labyrinths of information, Challenging the wisdom of systems. Oxford.

Espeland, W. N., \& Sauder, M. (2007). Rankings and Reactivity: How Public Measures Recreate Social Worlds. American Journal of Sociology, 113(1), 1-40. https://doi.org/10.1086/517897

Espeland, W. N., \& Sauder, M. (2016). Engines of anxiety: Academic rankings, reputation, and accountability. New York .

Kay, J. (2010). Obliquity: Why our goals are best achieved indirectly. London .

Kurunmäki, L., \& Miller, P. B. (2011). Regulatory hybrids: Partnerships, budgeting and modernising government. Management Accounting Research, 22(4), 220-241. https://doi.org/10.1016/j.mar.2010.08.004

Mouritsen, J. (1997). Tallelighedens regime. Synlighed, ansvarlighed og økonomistyring gennem mål og rammer $i$ statslige institutioner. København: Jurist- og Økonomforbundets Forlag.

Mouritsen, J. (2016). Fra virksomhed til tal og retur. In P. N. Bukh \& T. B. K. Kristensen (Eds.), Produktion og styring. Perspektiver på økonomistyringen (pp. 227-242). København: Jurist- og 
Økonomforbundets Forlag.

Mouritsen, J., \& Kreiner, K. (2016). Accounting, decisions and promises. Accounting, Organizations and Society, 49(1), 21-31. https://doi.org/http://dx.doi.org/10.1016/j.aos.2016.02.002

Murthy, V., \& Mouritsen, J. (2011). The performance of intellectual capital: Mobilising relationships between intellectual and financial capital in a bank. Accounting, Auditing and Accountability Journal, 24(5), 622-646. Retrieved from http://www.scopus.com/inward/record.url?eid=2-s2.079959582 113\&partnerID=40\&md5=e3579a9b75ddd 1035d8c95887c7b8ddf https://doi.org/10.1108/09513571111139120

Sauder, M., \& Espeland, W. N. (2009). The Discipline of Rankings: Tight Coupling and Organizational Change. American Sociological Review, 74(1), 63-82. https://doi.org/10.1177/000312240907400104

Schumpeter, J. A. (1943). Capitalism, socialism and democracy. London.

Strathern, M. (2000). The Tyranny of Transparency. British Educational Research Journal, 26(3), 309-32 1. https://doi.org/10.1080/713651562 